\title{
Problem Pengelolaan Zakat Ditinjauan dari Undang-Undang No 23 Tahun 2011 Tentang Pengelolaan Zakat
}

\author{
Ahmadin \\ STKIP Taman Siswa Bima \\ madin_uni15@yahoo.co.id
}

\begin{abstract}
ABSTRAK
Zakat sebagai salah satu rukun Islam yang wajib dijalankan, memiliki dua aspek, yaitu aspek agama dan aspek sosial ekonomi. Zakat ditinjau dari aspek agama merupakan suatu bukti kepatuhan seorang hamba kepada tuhan, dan dari aspek sosial-ekonomi, zakat memiliki fungsi strategis dalam mengentaskan kemiskinan dan mensejahterakan masyarakat. Oleh karena itu zakat sering kali disebut sebagai ibadah Maliyah Ijtimaiyyah. Namun fungsi zakat untuk pengentasan kemiskinan dan meningkatkan kesejahteraan akan terwujud jika zakat tidak hanya didistribusikan dalam bentuk konsumtif, melainkan dalam bentuk produktif, dimana zakat yang peroleh terlebih dahulu dimanfaatkan menjadi suatu usaha, yang kemudian dapat meningkatkan pendapatan dan memberikan penghasilan tetap, sehingga tujuan utama penyaluran zakat dapat terwujud yaitu merubah mustahik menjadi muzakki. Kemudian dilihat dari Pelaksanaan zakat merupakan langkah nyata untuk membangun sinergi sosial yang dapat dikembangkan secara kontekstual dalam kehidupan modern, misalnya orang yang memiliki modal menzakatkan modalnya kepada orang yang memiliki skill dan sebaliknya orang yang memiliki skill menzakatkan skillnya kepada yang memiliki modal. Maka zakat yang disebut dalam al-quran sejajar dengan shalat karena merupakan sarana komunikasi utama antara manusia dengan manusia lain dalam suatu tatanan kehidupan sosial.
\end{abstract}

Kata kunci: Zakat, Pengelolaan dan Problem

\section{PENDAHULUAN}

Dalam agama Islam, ada ajaran yang penting untuk diketahui bahwa dalam harta orang kaya terdapat hak orang lain yang harus dikeluarkan dalam bentuk zakat, infaq dan shadaqoh. Perintah menafkahkan harta, guna membantu sesama anggota masyarakat yang kurang beruntung tersebut merupakan pelaksanaan kongkrit dari prinsip Islam tentang keadilan sosial.

Cendekiawan Monzer Kahf (1995) mengatakan bahwa zakat dan sistem waris (faraidh) mengarah kepada distribusi harta yang egaliter, dan sebagai akibat dari zakat maka harta selalu beredar. Zakat mengandung banyak hikmah, baik yang berkaitan dengan hubungan manusia dengan tuhan maupun hubungan dengan sosial kemasyarakatan antar manusia. Zakat mengandung makna yang lebih luas dari pada sekedar pelaksanaan syariat islam.

Dari sisi ekonomi, zakat menghambat terjadinya penimbunan harta kekayaan yang menjadi sumber terciptanya kesenjangan sosial ekonomi dalam masyarakat, dan sebaliknya zakat mendorong pertumbuhan investasi dan menggugah etos kerja umat. Selain dari pada rukun islam yang menjadi salah satu unsur pokok bagi tegaknya syarit Islam, zakat juga disebut rukun masyarakat. Kalau seseorang melaksanakan shalat, puasa dan haji, manfaatnya kembali kepada dirinya sendiri. Orang lain dan masyarakat tidak rugi kalau ada orang islam yang meninggalkan shalat, puasa, atau haji. Lain halnya dengan zakat. Jika seorang muslim yang membayar zakat maka manfaatnya dirasakan langsung oleh orang lain dan masyarakat sekitanya. Sebaliknya, jika seseorang tidak membayar zakat pasti menimbulkan kerugian bagi banyak orang atau masyarakat pada umumnya karena rusaknya mekanisme penyeimbang sistem kepemilikan harta dan penghasilan.

Pelaksanaan zakat merupakan langkah nyata untuk membangun sinergi sosial yang dapat 
dikembangkan secara kontekstual dalam kehidupan modern, misalnya orang yang memiliki modal menzakatkan modalnya kepada orang yang memiliki skill dan sebaliknya orang yang memiliki skill menzakatkan skillnya kepada yang memiliki modal. Perintah menunaikan zakat atas harta dan penghasilan yang diperoleh, mendidik umat islam agar menjauhi sifat mementingkan diri sendiri dan sebaliknya mewujudkan semangat berbagi dengan orang lain. Kesadaran berzakat dipandang sebagai indikator utama ketundukan seseorang pada ajaran islam. Perintah mendirikan shalat didalam alquran tidak pernah dipisahkan dengan perintah membayar zakat, sebagaimana allah swt mensejajarkan iman dengan ukhuwah (persaudaraan sesama muslim) didalam kitab sucinya.

Allah swt berfirman: dirikanlah shalat dan tunaikanlah zakat. Apapun kebaikan yang kamu usahakan bagi dirimu, kamu akan mendapatkan pahalanya disisi allah swt. Sungguh, allah melihat atas segala yang kamu lakukan. (QS. Albaqaroh: 110).

Nabi muhammad saw dalam khutbah terakhirnya menegaskan, wahai manusia, tunaikanlah zakat hartamu. Ketahuilah, barang siapa tidak menunaikan zakat, tidak sempurna shalatnya. Ketahuillah, barang siapa tidak sempurna shalatnya, tidak sempurna pula agamanya, tidak sempurna puasanya dan tidak sempurna jihadnya.

Umar Hasyim dalam bukunya yang diterjemahkan dalam bahasa Indonesia berjudul pilar-pilar Islam yang dikutip dalam bukunya yang berjudul pedoman berzakat ditulis oleh kementerian agama, menjelaskan Allah maha bijaksana telah mengatur ukuran wajib mengeluarkan zakat sesuai dengan biaya dan tenaga dalam memperolehnya. Harta yang sedikit tenaga dalam memperolehnya lebih besar zakatnya.

Oleh karena itu, zakat yang disebut dalam alquran sejajar dengan shalat karena merupakan sarana komunikasi utama antara manusia dengan manusia lain dalam suatu tatanan kehidupan sosial. Zakat merupakan satu-satunya ibadah yang mempunyai petugas (amil) yang disebut secara eksplisit dalam al-quran. Agar lebih jelas makna yang sesungguhnya zakat. maka, perlu kita memberikan pengertian zakat.

\section{Pengertian Zakat}

Ditinjau dari segi bahasa, kata Zakat merupakan kata dasar (mashdar) dari Zakaa yag berarti berkah, tumbuh, bersih, dan baik. Sesuatu itu zakaa berarti sesuatu itu tumbuh dan berkembang, dan seseorang itu zakaa, berarti orang itu baik.

Dari kata zakaa, menjadi kata "zakat", yaitu sesuatu yang dikeluarkan oleh manusia dari sebagian hak Alloh SWT, untuk disalurkan kepada fakir miskin. Dinamai demikian karena padanya ada harapan mendapat berkah atau membersihkan jiwa atau menumbuhkannya dengan kebaikan dan berkah.

Zakat menurut bahasa adalah berkembang dan suci. Yakni membersihkan jiwa atau mengembangkan keutamaan-keutamaan jiwa dan menyucikannya dari dosa-dosa dengan menginfakkan harta di jalan Alloh dan menyucikannya dari sifat kikir, bakhil, dengki, dan lain-lain.

Zakat menurut syara' adalah memberikan (menyerahkan) sebagian harta tertentu untuk orang tertentu yang telah ditentukan syara' dengan niat karena Alloh.

Al-Mawardi dalam kitab Al-Hawi pernah berkata: "Zakat itu sebutan untuk pengambilan tertentu dari harta yang tertentu, menurut sifatsifat yang tertentu untuk diberikan kepada golongan tertentu."

Istilah zakat diberikan untuk beberapa arti. Namun yang berkembang dalam masyarakat, istilah zakat digunakan untuk shodaqoh wajib dan kata shodaqoh digunakan untuk shodaqoh sunat.

Zakat merupakan al'ibadah al-maaliyah alijtimaa'iyah (ibadah di bidang harta yang memiliki nilai sosial). Meskipun tergolong ibadah mahdloh dalam hal tata cara perhitungan dan pembagiannya, namun nilai sosial dalam ibadah zakat begitu kental, sehingga dalam pelaksanaannya diperlukan sekelompok yang bertugas mengelola segala aspek perzakatan, tidak diserahkan kepada kesadaran individu masing-masing. Hukum zakat yang wajib 
meniscayakan bahwa zakat bukan semata merupakan bentuk kedermawanan, melainkan bentuk ketaatan kepada Alloh SWT sehingga harus diperhatikan mengenai tata cara pembayaran dan pembagiannya. Oleh karena itu, para ulama fiqih kemudian memasukkan ibadah zakat sebagai qadla'iy (ibadah yang jika tidak dilaksanakan, ada hak orang lain yang terambil), bukan ibadah dayyaniy (ibadah yang jika tidak dilaksanakan tidak ada hak orang lain yang terambil), seperti sholat. Karena sifat zakat yang qadla'iy, maka pelaksanaan zakat tidak bisa dilakukan secara individual, oleh karena itu pada zaman rosululloh dan khulafaurraasyidin, pengelolaan zakat menjadi tugas dan tanggung jawab penguasa, bukan masyarakat secara perseorangan.

Zakat juga berarti tumbuh dan berkembang, Tumbuh dan berkembang ini bisa dilihat dari dua sisi, yaitu sisi muzakki (orang yang wajib mengeluarkan zakat) dan sisi mustahiq (orang yang berhak menerima zakat).

Pertama, dari sisi muzakki, Alloh SWT menjanjikan bagi siapa saja yang mau mengeluarkan hartanya dalam bentuk zakat, infaq, maupun shodaqoh, akan diberi ganjaran yang berlipat, tidak hanya di akhirat melainkan juga di dunia. Terbukti bahwa belum pernah ada seorang yang jatuh miskin dan bangkrut karena membayar zakat. Hal ini sebagaimana firman Alloh SWT:

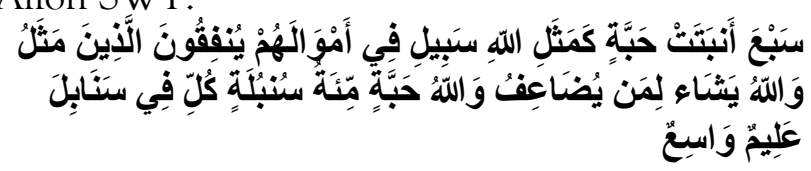

Artinya: "Perumpamaan (nafkah yang dikeluarkan oleh) orang-orang yang menafkahkan hartanya di jalan Alloh adalah serupa dengan sebutir benih yang menumbuhkan tujuh bulir, pada tiap-tiap bulir seratus biji. Alloh melipat gandakan (ganjaran) bagi siapa yang dia kehendaki. Dan Alloh maha luas (karunia-Nya) lagi maha mengetahui." (Q.S. Al-Baqoroh Ayat 261)

Dan Rosululloh SAW bersabda: "Tidak akan berkurang harta karena bersedekah, dan tidak akan dizholimi seseorang dengan kezholiman lalu ia bersabar atasnya, kecuali Alloh akan menambnya kemuliaan, dan tidaklah seorang hamba membuka jalan keluar untuk suatu permasalahan kecuali Alloh akan membebaskannya dari pintu kemiskinan atau semisalnya. (H.R. Tirmidzi).

Kedua, dari sisi mustahiq, dengan zakat yang diberikan secara terprogram bagi mustahiq, akan bisa mengembangkan harta yang dimilikinya, bahkan akan mampu mengubah kondisi seseorang yang asalnya mustahiq menjadi muzakki.

\section{Hukum Zakat}

Hukum zakat adalah wajib. Zakat adalah sebuah kewajiban individu (fardhu 'ain) yang wajib dikeluarkan oleh seorang muslim yang memiliki harta tertentu, dan diambil oleh para petugas zakat. Perhatikan firman Allah SWT dibawah ini:

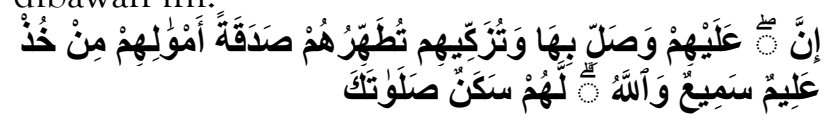

Artinya: "Ambillah zakat dari sebagian harta mereka, dengan zakat itu kamu membersihkan dan mensucikan mereka dan berdoalah untuk mereka. Sesungguhnya doa kamu itu (menjadi) ketentraman jiwa bagi mereka. Dan Alloh maha mendengar lagi maha mengetahui". (Q.S AtTaubah ayat 103)

\section{Ancaman Untuk Orang Yang Tidak Mau} Mengeluarkan Zakat

Bagi mereka yang sudah kena kewajiban zakat, tapi tidak mau membayarnya, maka siksa yang sangat pedih akan mereka terima di akherat kelak. Bahkan ancaman Alloh SWT demikian kerasnya. Alloh SWT berfirman didalam AlQuran surat At-Taubah ayat 34-35 yang artinya: "Orang-orang yang menimbun emas dan perak dan tidak menafkahkannya di jalan Alloh, peringatkanlah mereka tentang adzab yang pedih. Pada hari emas dan perak dipanaskan dalam api neraka, lalu dibakar dengannya dahidahi mereka, rusuk-rusuk, dan punggung, dan dikatakan kepada mereka, "Inilah kekayaan yang kalian timbun dahulu, rasakanlah oleh kalian kekayaan yang kalian simpan itu." (Q.S. AtTaubah ayat 34-35).

\section{Orang Yang Berhak Menerima Zakat}

Orang yang berhak menerima zakat atau sering disebut dengan mustahiq zakat adalah seperti yang Alloh SWT firmankan dalam quran 
surat At-Taubah ayat 60 yang artinya: "Sesungguhnya zakat-zakat itu hanyalah untuk orang-orang fakir, orang-orang miskin, para pengurus zakat (amilin), para mu'allaf yang dibujuk hatinya, untuk (memerdekakan) budak. Orang-orang yang berutang, untuk jalan Alloh, dan orang-orang yang sedang dalam perjalanan, sebagai suatu ketetapan yang diwajibkan Alloh; dan Alloh maha mengetahui lagi maha bijaksana". (Q.S At-Taubah: 60)

Dari ayat tersebut bisa kita ambil kesimpulan bahwa mustahiq zakat itu ada 8 ashnaf (bagian). Yaitu sebagai berikut: 1) Fakir ialah orang yang tidak bisa memenuhi kebutuhan primer (kebutuhan sehari-hari) karena tidak bisa kasab (usaha); 2) Miskin ialah orang yang bisa kasab (usaha) tapi tidak mencukupi kebutuhan primer (kebutuhan sehari-hari); 3) Amilin ialah orang yang diangkat oleh pemimpin untuk menggarap tugas-tugas pemungutan atau pengumpulan, pendayagunaan atau pemeliharaan, pencatatan dan atau pelaporan, serta Pendistribusian atau pembagian zakat;

Muallaf ialah orang yang dijinakkan hatinya untuk kepentingan islam dan kaum muslimin; 5) Riqob adalah membebaskan atau memerdekakan hamba sahaya dari perhambaannya (budak) sehingga ia lepas dari ikatan dengan tuannya; 6) Ghorimin adalah orang-orang yang tenggelam dalam utang dan tidak mampu membayar. Utang tersebut bukan untuk maksiat, penghamburan, atau karena kebodohan, belum dewasa, dll; 7) Fii sabiilillah adalah kemaslahatan umum kaum muslimin yang dengan zakat itu berdiri islam dan daulahnya dan bukan untuk kepentingan pribadi; dan 8) Ibnu sabil adalah orang yang kehabisan ongkos di perjalanan dan tidak bisa mempergunakan hartanya.

\section{Macam Macam Zakat}

Secara global, zakat terbagi kepada dua bagian, yaitu zakat fitrah dan zakat maal; 1) Zakat Fitrah atau zakat badan adalah zakat yang wajib dikeluarkan satu kali dalam setahun oleh setiap muslim mukallaf (orang yang dibebani kewajiban oleh Alloh) untuk dirinya sendiri dan untuk setiap jiwa yang menjadi tanggungannya. Jumlahnya sebanyak satu Sha' (1.k 3,5 liter/2,5
$\mathrm{Kg}$ ) per orang, yang didistribusikan pada tanggal 1 Syawal setelah sholat shubuh sebelum sholat Iedul Fitri. Hukum zakat fitrah adalah wajib. Seperti yang diterangkan dalam hadits yang diterima oleh Ibnu Abbas yang artinya: "Rosululloh SAW telah mewajibkan zakat fitri untuk menyucikan orang yang shaum dari segala perkataan yang keji dan buruk yang mereka lakukan selama mereka shaum, dan untuk menjadi makanan bagi orang-orang yang miskin". (H.R. Abu Daud); dan 2) Zakat Maal/Zakat Harta terdiri dari beberapa macam, yaitu: a) Zakat Emas, Perak, dan Uang. Zakat ini hukum nya wajib seperti yang Alloh firmankan dalam quran surat At-Taubah ayat 34-35 (silahkan lihat diatas). Orang yang mempunyai emas wajib mengeluarkan zakat ketika sudah sampai pada nishabnya, Nishab emas sebesar 20 dinar (90 gram), nishab perak sebesar 200 dirham (600 gram), dan kadar zakatnya sebanyak 2,5\%. Dan zakat ini dikeluarkan ketika sudah mencapai haul (setahun sekali), maksudnya ketika seseorang mempunyai emas yang sudah mencapai nashab (90 gram) dan disimpan/dipunyai selama satu tahun, maka wajib mengeluarkan zakat; b) Zakat Ziro'ah (pertanian/segala macam hasil bumi) Yaitu zakat dari pertanian. Zakat ini wajib seperti yang dijelaskan Alloh SWT dalam quran surat AlAn'am ayat 141; c) Zakat Ma'adin (barang galian). Maksud ma'adin yaitu segala yang dikeluarkan dari bumi; d) Zakat Rikaz (harta temuan/harta karun). Yang dimaksud rikaz adalah harta (barang temuan) yang sering dikenal dengan istilah harta karun. Tidak ada nishab dan haul, besar zakatnya 20\%; e) Zakat Binatang Ternak. Orang yang memelihara hewan ternak wajib mengeluarkan zakatnya; f) Zakat Tizaroh (perdagangan). Ketentuan zakat ini adalah tidak ada nishab, diambil dari modal (harga beli), dihitung dari harga barang yang terjual sebesar 2,5\%.

\section{Manajemen Zakat}

Pada bulan Ramadhan, umat Islam selain diperintahkan untuk berpuasa, juga diperintahkan berzakat, terutama zakat fitrah, baik yang berupa makanan pokok maupun berupa uang yang seharga dengan hitungan 
makanan pokok. Zakat merupakan salah satu ibadah yang mengandung dimensi vertikal (manusia-Tuhan) dan horizontal (manusiamanusia) sekaligus. Secara vertikal, zakat adalah perintah Allah kepada manusia yang wajib ditunaikan dan itu sudah final (tauqify), tidak bisa ditawar-tawar lagi. Secara horizontal, pengelolaan zakat untuk disalurkan kepada yang berhak (mustahiq) terbuka peluang untuk ijtihad (ijtihady).

Aspek horizontal inilah yang perlu didiskusikan dan dikembangkan terus-menerus mengingat zakat memiliki potensi yang besar dalam menyejahterakan rakyat dan mengandung nilai humanisme, tapi pengelolaannya selama ini belum maksimal.

Tragedi pembagian zakat yang memakan korban (mati, terinjak, berdesak-desakan) di sejumlah daerah, seperti yang terjadi di Pasuruan, beberapa tahun lalu, merupakan contoh kecil dari buruknya manajemen dan strategi.

Dalam hal ini, setidaknya ada empat unsur penting yang harus dipenuhi. Pertama, badan atau lembaga sebagai pengumpul zakat bisa berupa Islamic Center, masjid, dan lain-lain. Kedua, proses kerja, yakni sebuah usaha untuk mengumpulkan, mengelola, mengoptimalkan, dan memberikan zakat. Ketiga, orang yang melakukan proses dalam hal ini adalah amil zakat. Keempat, tujuan, yakni terkumpul sekurang-kurangnya 25-50 persen dari wajib zakat.

Untuk melakukan kerja-kerja tersebut, seorang manajer akan melakukan kegiatankegiatan yang disebut fungsi manajemen sebagai berikut. Pertama, planning, yakni harus ditentukan goal yang ingin dicapai dalam waktuÂ tertentu di masa depan dan apa yang harus dilakukan untuk mencapai tujuan tersebut.

Kedua, organizing, harus ada pengelompokan kegiatan dan pembagian tugas terhadap apa yang akan dikerjakan dalam rangka mencapai goal tersebut. Ketiga, staffing, harus ada penentuan sumber daya manusia yang diperlukan, pemilihan mereka, pemberian trainning, dan pengembangannya. Keempat, motivating, pemberian motivasi dan arahan untuk menuju goal. Kelima, controlling, pengukuran performance untuk mencapai goal yang telah itentukan, penentuan sebab-sebab terjadinya penyimpangan dari goal, dan sekaligus usaha pelurusan kembali untuk menuju goal yang ada. Fungsi manajemen yang standar di atas acapkali diabaikanâ€”untuk mengatakan dianggap tidak penting. Padahal, tanpa fungsi manajemen tersebut, pengorganisasian apa pun akan tidak maksimal dan tidak tepat sasaran. Akhirnya, tujuan mulia zakat hanya menguap begitu saja di udara. Naudzubillah. Apabila fungsi manajemen dilakukan dengan baik (well-done), tinggal dilakukanlah strategi-strategi pembangunan zakat.

Potensi dana zakat dan realisasi pengumpulannya dapat gap yang besar. Salah satu bentuk sosialisasinya adalah kampanye sadar zakat yang dilakukan oleh komponen bangsa, bahkan kalau perlu sosialisasi tersebut dilakukan mulai dari tingkat presiden sampai RT. Pasalnya, masyarakat hanya menyadari bahwa zakat fitrah sajalah yang wajib di bayarkan. Padahal, masih banyak jenis zakat lainnya yang harus dibayarkan, seperti zakat ternak, tanaman, profesi, dan lain-lain.

Bahkan, mungkin juga perlu dibentuk semacam NPWZ (nomor pokok wajib zakat) sebagai bukti keterlibatan mereka dalam mendukung sosialisasi zakat. Seiring perkembangan teknologi informasi, zakat pun sebenarnya bisa dilakukan dengan media IT sebagaimana di Singapura dan Malaysia, yakni eZakat: Zakat System Online.

Kedua, membangun citra lembaga zakat yang amanah dan profesional. Hal ini penting untuk dilakukan mengingat saat ini telah terjadi krisis kepercayaan antarsesama komponen masyarakat.

Pembangunan citra ini merupakan hal yang sangat fundamental. Citra yang kuat dan baik akan menggiring masyarakat yang berka tegorikan muzaki untuk mau menyalurkan dana zakat melalui amil. Amanah, equitable, akuntabilitas, transpa ransi, dan coorporate culture merupakan tiga hal pokok dalam menentunkan citra lembaga zakat (zakat coorporation) yang profesional. 
Ketiga, membangun sumber daya manusia yang siap berjuang dalam mengembangkan zakat di Indonesia. Keempat, memperbaiki dan menyempurnakan perangkat peraturan tentang zakat di Indonesia, termasuk merevisi Undangundang No. 38/1999. Hal ini sangat penting mengingat UU tersebut merupakan landasan legal formal bagi pengelolaan zakat secara nasional. Di Yordania, misalnya, pemerintahnya sangat memperhatikan aspek perundangundangan zakat. Mereka menghapus hukum zakat tahun 1944 dengan Undang-Undang Pajak Pelayanan Sosial tahun 1978, diperkuat lagi dengan Undang-Undang Zakat Fund tahun 1978 sebagai bentuk otonomi untuk mendirikan Funding Zakat, pembentukan direktorat zakat untuk ibu kota provinsi, dan ada pula sekitar 43 Komite Valuntary Zakat dan ahli-ahli syariah zakat di bawah Kementerian Awqaf.

Di Indonesia, perlu adanya inovasi-inovasi dan pengembangan ke arah yang lebih baik terkait dengan undang-undang zakat. Kelima, membangun database mustahik dan muzaki secara nasional sehingga diketahui peta penyebarannya secara tepat.

Indikator seorang dinilai mustahik maupun muzaki juga harus diatur secara jelas, tepat, dan di sesuaikan kondisi yang ada. Keenam, menciptakan standar disasi mekanisme kerja Badan Amil Zakat (BAZ) dan Lembaga Amil Zakat (LAZ) sebagai parameter kinerja kedua lembaga tersebut.

Selama ini, belum ada standar baku dalam praktiknya. Ini menjadi hal urgen agar masyarakat memiliki ukuran yang jelas dalam mengontrol pengelolaan zakat.

\section{Perbedaan Pajak dengan Zakat}

Zakat berbeda dengan pajak, karena; a) Zakat adalah suatu kewajiban agama dan merupakan ibadah, sedangkan pajak adalah iuran yang diambil untuk mengumpulkan pendapatan negara; b) Zakat dipungut dari kaum muslim saja, sedangkan pajak dipungut dari seluruh warga negara bersangkutan tanpa memandang status sosial, kepercayaan, ataupun warna kulit; c) Zakat adalah tugas wajib kaum muslim yang harus dijalankan dalam segala keadaan dan sama sekali tidak boleh dikurangi, sedangkan pajak dapat dikurangi oleh pemerintah; d) Berbeda dengan pajak, sumber dan tarif zakat telah ditentukan Al Qur'an dan Sunnah, serta tidak dapat diubah dari waktu ke waktu sesuai dengan keperluan pemerintah dari negara; e) Jenis harta yang terkena zakat serta pihak-pihak yang berhak menerimanya sudah ditetapkan oleh Al Qur'an dan Sunnah. Adapun pembelanjaan pajak dapat saja dimodifikasi sesuai kebutuhan pemerintah; f) Zakat diterima dari orang kaya dan dibelanjakan untuk orang miskin serta yang membutuhkan, sedangkan pajak menguntungkan baik yang kaya maupun miskin; dan, dalam kondisi tertentu bahkan lebih menguntungkan orang kaya daripada orang miskin; g) Zakat dipungut dari total harta yang ada pada si pemilik selama setahun penuh (bukan dari penghasilan kotor-ed.); dan h) Pungutan zakat pada dasarnya bertujuan mencegah distribusi harta kekayaan yang tidak merata dan tidak adil dan pemusatan kekayaan, sedangkan pajak dipungut terutama untuk tujuan-tujuan pendapatan negara.

\section{Problem Pengeloaan Zakat}

Dalam perkembangan zaman, pengelolaan zakat di Indonesia menghadapi beberapa kendala atau hambatan sehingga seringkali pengelolaannya masih belum optimal dalam perekonomian. Adapun hambatan-hambatan tersebut adalah; 1) Minimnya sumber daya manusia yang berkualitas. Pekerjaan menjadi seorang pengelola zakat (amil) belumlah menjadi tujuan hidup atau profesi dari seseorang, bahkan dari lulusan ekonomi syariah sekalipun. Para pemuda ini -meskipun dari lulusan ekonomi syariah- lebih memilih untuk berkarir di sektor keuangan seperti perbankan atau asuransi, akan tetapi hanya sedikit orang yang memilih untuk berkarir menjadi seorang pengelola zakat. Menjadi seorang amil belumlah menjadi pilihan hidup dari para pemuda kita, karena tidak ada daya tarik berkarir di sana. Padahal lembaga amil membutuhkan banyak sumber daya manusia yang berkualitas agar pengelolaan zakat dapat profesional, amanah, akuntabel dan transparan. Karena sesungguhnya kerja menjadi seorang amil mempunyai dua aspek tidak hanya aspek materi 
semata namun aspek sosial juga sangat menonjol.

Ada beberapa kriteria pengelola zakat agar mampu menjadi suatu lembaga zakat yang profesional, yaitu (1) Amanah; (2) Manajerial Skills; (3) Ikhlas; (4) Leadership Skills; (5) Inovatif; (6) No Profit Motives; b) Pemahaman fikih amil yang belum memadai. Masih minimnya pemahaman fikih zakat dari para amil masih menjadi salah satu hambatan dalam pengelolaan zakat. Sehingga menjadikan fikih hanya dimengerti dari segi tekstual semata bukan konteksnya. Banyak para amil terutama yang masih bersifat tradisional, mereka sangat kaku memahami fiqih, sehingga tujuan utama zakat tidak tercapai. Sebenarnya dalam penerapan zakat di masyarakat yang harus diambil adalah ide dasarnya, yaitu bermanfaat dan berguna bagi masyarakat serta dapat memberikan kemaslahatan bagi umat dan mampu menjadikan mustahik tersebut pribadi yang mandiri dan tidak tergantung oleh pihak lain.

Namun bukan berarti para amil diberikan kesempatan untuk berijtihad dan berkreasi tanpa batas, mereka tetap harus berusaha melakukan terobosan-terobosan baik pengelolaan zakat, agar tetap sesuai dengan syariah. Sistem pengawasan yang terdapat di semua institusi keuangan syariah termasuk di dalamnya institusi pengelola zakat, mewajibkan adanya unsur Dewan Pengawas Syariah di dalam struktur organisasinya yang berfungsi untuk melakukan pengawasan terhadap pengelolaan manajemen agar tidak menyimpang dari aturan syariat; c) Rendahnya kesadaran masyarakat. Masih minimnya kesadaran membayar zakat dari masyarakat menjadi salah satu kendala dalam pengelolaan dana zakat agar dapat berdayaguna dalam perekonomian. Karena sudah melekat dalam benak sebahagian kaum muslim bahwa perintah zakat itu hanya diwajibkan pada bulan Ramadhan saja itupun masih terbatas pada pembayaran zakat fitrah. Padahal zakat bukanlah sekedar ibadah yang diterapkan pada bulan Ramadhan semata, melainkan juga dapat dibayarkan pada bulan-bulan selain Ramadhan. Sehingga ide dasar zakat untuk kemaslahatan umat telah bergeser menjadi sekedar ibadah ritual semata yang dikerjakan bersamaan dengan ibadah puasa. Terdapatnya syarat haul (satu tahun kepemilikan) menandakan bahwasanya zakat tersebut tidak mengenal pembayaran pada satu bulan tertentu saja, melainkan setiap bulan zakat dapat dibayarkan. Apabila kesadaran masyarakat akan pentingnya zakat bagi peningkatan kesejahteraan dan kemakmuran umat sudah semakin baik, hal ini akan berimbas pada peningkatan penerimaan zakat; d) Teknologi yang digunakan. Penerapan teknologi yang ada pada suatu lembaga zakat masih sangat jauh bila dibandingkan dengan yang sudah diterapkan pada institusi keuangan. Hal ini turut menjadi salah satu kendala penghambat kemajuan pendayagunaan zakat. Teknologi yang diterapkan pada lembaga amil masih terbatas pada teknologi standar biasa. Sistem akuntansi, administrasi, penghimpunan maupun pendayagunaan haruslah menggunakan teknologi terbaru, agar dapat menjangkau segala kelompok masyarakat terutama segmen kalangan menengah atas yang notabenenya memiliki dana berlebih. Mobilitas tinggi membutuhkan teknologi tinggi yang menunjang pula, bila lembaga amil zakat mampu melakukan inovasi dalam memberikan kemudahan kepada muzakki, maka akan semakin mampu mempertinggi proses penghimpunan dana. Misalkan melakukan kerjasama dengan perbankan untuk pembayaran zakat via atm atau mobile-banking. Penggunaan teknologi selain memberikan kemudahan kepada muzakki untuk memberikan donasinya, akan turut pula mempermudah lembaga amil zakat pada penghimpunan dana di masyarakat dan e) Sistem informasi zakat. Inilah salah satu hambatan utama yang menyebabkan zakat belum mampu memberikan pengaruh yang signifikan dalam perekonomian. Lembaga amil zakat yang ada belum mampu mempunyai atau menyusun suatu sistem informasi zakat yang terpadu antar amil. Sehingga para lembaga amil zakat ini saling terintegrasi satu dengan lainnya. Sebagai contoh penerapan ini adalah pada database muzakki dan mustahik. Dengan adanya sistem informasi ini tidak akan terjadi pada muzakki yang sama didekati oleh beberapa lembaga amil, atau 
mustahik yang sama diberi bantuan oleh beberapa lembaga amil zakat.

Namun bukan berarti dengan adanya sistem informasi zakat ini, maka tidak ada lagi rahasia dan strategi khas antar institusi. Sebab kehadiran sistem informasi zakat adalah hanya untuk mempermudah mengenali titik-titik lokasi yang telah digarap oleh suatu lembaga, dan titik lokasi mana yang belum menerima bantuan. Hal ini dapat mencegah dimana akan terdapat lokasi pemberdayaan yang "gemuk" dan ada lokasi yang "kurus". Karena tujuan utama kehadiran lembaga amil zakat selain untuk mengelola dana zakat, namun harus pula mampu mengkoordinasikan agar zakat tersebut manfaat dan pengaruhnya dapat terasa bagi peningkatan kemakmuran dan kesejahteraan masyarakat. Akan tetapi sistem informasi ini haruslah dikelola oleh suatu institusi independen, dan idealnya dikelola oleh negara. Kelima hambatan inilah yang harus dipecahkan secara bersamasama oleh setiap elemen dalam pengelolaan zakat, sebab tanpa kerjasama aktif antar institusi baik dari swasta maupun pemerintah hambatanhambatan ini tidaklah akan dapat terwujud.

\section{Pemanfaatan Zakat Sesuai Undang-Undang Nomor 23 Tahun 2011 Pengelolaan Zakat.}

Pemerintah ingin menjadi aktor yang dapat memiliki langkah strategis dalam mendorong keberhasilan pengelolaan zakat di Indonesia. Karena dukungan pemerintah dan perannya akan berdampak positif bagi kehidupan negara secara menyeluruh terhadap bangsa. Sangatlah wajar apabila pemerintah melalui hak kekuasaanya ingin mensejahterakan masyakatnya.

Oleh karena sebagian besar masyarakat muslim Indonesia adalah miskin maka pemerintah ikut bertanggung jawab untuk mengentaskan kemiskinan melalui zakat. Karena zakat adalah sebuah jangkar Islam dalam mengatasi kemiskinan dengan keadilan meningkatkan kesejahteraan masyarakatnya. menurut jenisnya secara garis besar, organisaasi amil zakat dibedakan menjadi dua, yaitu yang dikelola oleh pemerintah disebut badan amil zakat nasional dan yang dikelola swasta atau masyarakat dan dikukuhkan oleh pemerintah, disebut dengan Lembaga Amil Zakat (LAZ). serta Badan Amil Zakat yang dibentuk secara tingkat nasional disebut BAZNAS yang membawahi tingkat propinsi dan kabupaten/kota, serta dapat membentuk unit pengumpul zakat (UPZ).

Sebenarnya sudah sekitar 49 tahun lamanya pemerintah Indonesia ingin membuat undangundang zakat. mulai tahun 1950-an sudah dicetuskan perumusan tentang Undang-Undang tersebut, hingga pada tahun 1999 UndangUndang No. 23 tahun 2011 tentang pengelolaan zakat disahkan. namun kenyataannya, UndangUndang ini seolah hanya berjalan di tempat, tetapi belum efektif untuk mengkondisikan masyarakat agar gemar menunaikan zakat melalui lembaga. Manfaat dengan di undangkannya UU No. 38 Tahun 1999 yang berdampak langsung terhadap keberadaan lembaga pengumpul zakat yang secara legal dapat memungut zakat. selain itu, belum ada manfaat yang sangat signifikan terhadap diberlakukannya undang-undang tersebut.

Kemudian di tahun 2011 terdapat amandemen Undang-Undang tentang zakat yang dsidangkan pada tanggal 27 Oktober 2011. Pada Undang-Undang ini mengandung muatan inti dalam pengelolaan zakat: a) Pengelolaan zakat menjadi kewenangan Negara, masyarakat hanya diperkenankan ikut mengelola apabila ada ijin dari pemerintah; b) Pengelolaan zakat dilakukan oleh BAZNAS yang beroperasi dari tingkat pusat sampai tingkat kabupaten/kota secara hirarkis (untuk selanjutnya BAZNAS dapat membentuk UPZ); c) Anggota BAZNAS terdiri dari 8 orang perwakilan masyarakat terdiri dari ulama, tenaga profesional dan tokoh masyarakat, sedangkan perwakilan pemerintah dari unsur perwakilan kementerian agama terkait; d) Lembaga Amil Zakat (LAZ) berperan sebagai pembantu BAZNAS dalam mengelola zakat (untuk selanjutnya LAZ dapat membentuk perwakilan).

Dan alasan dikeluarkannya Undang-Undang tantang zakat ini, karena pemerintah ingin mengendalikan pengelolaan zakat disektor Desa hingga pusat supaya dapat dimanfaatkan oleh seluruh masyarakat di Indonesia yang sebahagian besar masyarakat Indonesia adalah muslim yang 
miskin, maka pemerintah ingin samaratakan kesejahteraannya melalui zakat.

\section{KESIMPULAN}

Penghasilan atau rezeki yang diperoleh setiap orang adalah datangnya allah SWT dan kembalinya kepada Allah SWT. Mengingat harta yang diperoleh tersebut bukan sepenuhnya menjadi miliknya dan masih terdapat milik orang lain mengingat rezeki merupakan problem yang paling utama, sehingga dengan kemiskinan dapat menimbulkan kekufuran, maka tepat pada bulan syawal tahun ke 2 Hijriyah pada bulan ramadhan diwajibkan zakat fitrah, kemudian diwajibkan zakat mal atau kekayaan yang harus dikeluarkan.

Pada zaman dinasti umawiyah dan abbasyah diupayakan pengkajian fiqih zakat kemudian bermunculan fuqaha-fuqaha dan memulai kajian-kajian monumentalnya yang menuangkan renungan ijtihad dengan menguraikan secara lengkap mulai dari konsep dasar hukum dan etika penyaluran zakat sesuai dengan perkembangan dan kebutuhan waktu itu dengan mengkategorikan dengan dua hal: a) Zakat merupakan bagian ibadah dan rukun islam, secara doktrin terkait dengan nilai-nilai yang diangkat dari al-Quran dan sunnah sehingga orang muslim bertanggung jawab untuk mensosialisasikannya; b) Zakat disadari mempunyai dimensi sosial ekonomi umat sebagai insturment pemerataan rezeki untuk menanggulangi problem ekonomi umat islam dan menjadi tumpuan menanggulangi kemiskinan.

Dari dua hal tersebut dapat diambil bahwa zakat adalah sebagai jalan pemerataan rezeki terhadap seseorang sebagaimana halnya pada masa kejayaan islam khalifah umar memilih memerangi memerangi kelompok-kelompok masyarakat yang menolak untuk membayar zakat. Sebagaimana dalam suatu khutbahnya “ demi allah saya akan berperang melawan mereka yang membedakan antara shalat dan zakat”.
Ali, Nuruddin (2006) Zakat Sebagai Instrument Kebijakan Fiskal Dalam,. Jakarta: PT Raja Grafindo Persada

Dirjen Bimas Islam, Depag RI (2009) Fiqih Zakat, Manajemen Pengelolaan Zakat dan Wakaf Paradigma Baru. Jakarta: Depag RI

Ichsan, M Surjani dan Tim (2009) Pedoman Aplikasi Untuk Kriteria Manajemen Zakat Unggul. Jakarta: Forum Zakat

Khan, Mumtaz Ali (2003) Zakat dan Amal Harus Menjadi Alat Untuk Mengembangkan Masyarakat Miskin. Diperoleh dari islamicvoice. Situs web.: http://www.Islamicvoice.com

Qaradhawi, Yusuf (2005) Spektrum Zakat Dalam Membangun Ekonomi Kerakyatan. Jakarta: Zikrul

Pedoman Zakat seri ke 9, (2010) Kantor Kementerian Agama Nusa Tenggara Barat Undang-Undang Nomor 23 Tahun 2011 Tentang Pengelolaan Zakat

\section{DAFTAR PUSTAKA}

